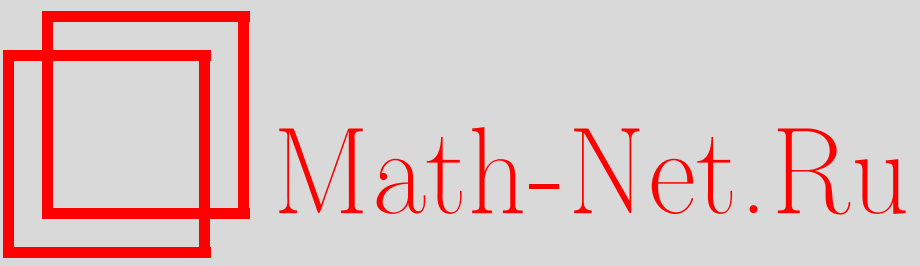

Журналу "Теоретическая и математическая физика" 30 лет, ТМФ, 1999, том 121 , номер 1, 3

DOI: https://doi.org/10.4213/tmf794

Использование Общероссийского математического портала Math-Net.Ru подразумевает, что вы прочитали и согласны с пользовательским соглашением

http://www . mathnet.ru/rus/agreement

Параметры загрузки:

IP : 3.80 .253 .173

26 апреля 2023 г., 12:48:17 


\section{ЖУРНАЛУ “ТЕОРЕТИЧЕСКАЯ И МАТЕМАТИЧЕСКАЯ ФИЗИКА" 30 ЛЕТ}

Тридшать лет назад, в октябре 1969 года вышел первый номер нашего журнала.

В течение 50-х и 60-х годов в соответствии с мировыми тенденциями развития естествознания и в значительной степени благодаря трудам Николая Николаевича Боголюбова и его школы в теоретической физике все бо́льшую роль стали играть методы современной математики, такие как теория обобшенных функций, аксиоматический подход, теория функций многих комплексных переменных, теория групп Ли. Постепенно стал вырабатываться новый стандарт уровня строгости теоретических исследований, общепризнанный в наши дни. Однако сушествовавшие в то время отечественные физические и математические журналы, как правило, испытывали затруднения при рассмотрении статей, написанных в новом духе. Журнал "Теоретическая и математическая физика" естественным образом заполнил образовавшуюся нишу, взяв на себя освешение важнейших достижений в развитии фундаментальных направлений теоретической физики, характеризуюшихся высоким уровнем математической строгости. Он явился одним из первых изданий нового направления в мировой периодической литературе.

В первый состав редколлегии вошли Н.Н. Боголюбов - главньй редактор, В.С. Владимиров - заместитель гл. редактора, А.Н. Тавхелидзе - заместитель гл. редактора, М. К. Поливанов - ответственный секретарь, А. А. Ансельм, В.Б. Берестецкий, Д.И. Блохинцев, А.С. Давыдов, Д.Н. Зубарев, А.А. Комар, А. А. Логунов, М.А. Марков, В.П. Маслов, Б.В. Медведев, Ю.В. Новожилов, А.З. Петров, В. Г. Соловьев, Л.Д. Соловьев, Л.Д. Фаддеев, Е.С. Фрадкин, И. М. Халатников, О.А. Хрусталев, Г. А. Чилашвили, В.П. Шелест, Д. В. Ширков. С самого основания журнала Редакцией ТМФ заведует Т.В. Рогозкина.

Следуя изначальным принципам, лаконично выраженным эмблемой $\mathrm{M} \cap \Phi$, и традициям боголюбовской школы, ТМ $Ф$ постепенно превратился в журнал широкого профииля, освешаюший наиболее актуальные направления современной теоретической и математической физики.

В связи с тридцатилетием журнала ТМФ мы хотим еще раз выразить уважение и признательность всем, кто создавал его и содействовал его становлению и развитию.

В этом юбилейном номере, в частности, продолжается публикация статей, посвященных памяти основателя ТМ $\Phi$, одного из крупнейших ученых нашего столетия Николая Николаевича Боголюбова в связи с 90-летием со дня его рождения. 